\title{
Perspective
}

PERSPECTIVE Actualité en histoire de l'art

1 | 2012

Art et pouvoir

\section{Re-making French revolutionary iconoclasm}

Repenser l'iconoclasme révolutionnaire français

\section{Richard Clay}

\section{(apenEdition}

Journals

Electronic version

URL: http://journals.openedition.org/perspective/633

DOI: 10.4000/perspective.633

ISSN: 2269-7721

\section{Publisher}

Institut national d'histoire de l'art

\section{Printed version}

Date of publication: 30 June 2012

Number of pages: 181-186

ISSN: 1777-7852

\section{Electronic reference}

Richard Clay, « Re-making French revolutionary iconoclasm », Perspective [Online], 1 | 2012, Online since 30 December 2013, connection on 01 October 2020. URL : http://journals.openedition.org/ perspective/633 ; DOI : https://doi.org/10.4000/perspective.633 


\section{Re-Making French Revolutionary Iconoclasm}

\section{Richard Clay}

\section{Vandalism and the autonomy of art}

As Peter Weibel has written, "Since the French Revolution, the breaking of images and destruction of idols has been linked to the rhetoric of progressive revolutionary politics" ${ }^{1}$. His comments point to the ongoing resonance of what one might call the "iconoclasm" (etymologically, "image breaking") of the revolutionary decade in France and, indeed, its historiography. In 2011 , global news coverage of the struggle to topple the Gaddafi regime in Libya regularly included films or photographs of Libyans defacing, pulling down, trampling, or burning images associated with the temporal government whose authority they were challenging. The breaching of representational objects' physical integrity continues to be a means by which diverse groups and individuals represent and imagine contested power relations between a state, its citizens, and wider communities. Significantly, none of the Western news reports of the recent events described above seemed to acknowledge any contemporary condemnation of the perpetrators. No interviews were disseminated with the artists whose work was damaged, and no reports featured supporters of the regimes who on political or historical grounds could have regarded as valuable the damaged objects ${ }^{2}$. In contrast, when the Bamiyan Buddhas in northern Afghanistan were destroyed over the course of several days by the Taliban in 2001, media outlets widely reported UNESCO's condemnation of an act of "vandalism" that involved objects whose historical and aesthetic worth the organization acknowledged ${ }^{3}$ (fig. 1).

Tellingly, the Taliban's actions were labeled with a term that was coined during the French Revolution to connote the alleged barbarism of contemporaries whose damaging of representational objects was considered comparable to the behavior of the German tribe, the Vandals, which sacked ancient Rome ${ }^{4}$. The term's original users, like the authors of the available books on "vandalism" during the French Revolution and UNESCO, implicitly recognized targeted objects as being privileged products of a civilization's material culture that were of such aesthetic and historical worth that they should be regarded as being set apart from wider struggles in the world. Scholars focusing on treatment of the Bamiyan Buddhas, on the other hand, like more recent historians of the Revolution, have avoided the pejorative phrase "vandalism" and deployed alternatives deemed more appropriate by researchers aspiring to the unachievable goal of objectivity ${ }^{5}$. Implicitly or explicitly, the authors acknowledge that the value given to representational objects can vary from viewer to viewer and that academics should be wary of using their own culturally specific value systems when explaining, rather than condemning or condoning, the behavior of the people whom they study.

Since the publication of Le Vandalisme jacobin by Gustave Gautherot in $1914^{6}$, only two monograph-length studies have focused on iconoclasm during the Revolution; tellingly, both books also referred to "vandalism" in their titles. The first, by Louis Réau, appeared in 1959 and was republished in a longer form in 19947; the second, by François Souchal, was published in $1990^{\circ}$. Both authors made key contributions to their field of study, offering widely researched (if often poorly referenced) surveys of a vast and complex field. They made extensive use of newspapers and pamphlets, diary entries, letters, and the mass of detailed official records pertaining to government programs of iconoclasm that followed the
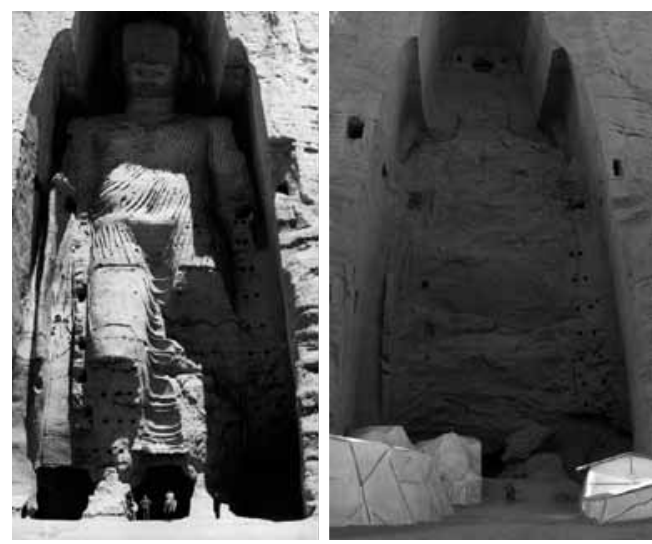

1. The larger of the Bamiyan Buddhas, in 1963 (left) and after destruction by the Taliban in 2001 (right). 
proscription of signs of feudalism, of royalty in 1792, and of "superstition" in 1793, as well as unofficial acts throughout the period. Although both authors also engaged with comparably extensive records relating to the official preservation of objects - an area that is also the focus of a rich historiography ${ }^{9}-$, Réau's and Souchal's emphasis lay firmly on describing, accounting for and condemning damage they labelled as "vandalism", rather than on contemporaneous preservationist practices and debates. In trying to explain the alleged barbarism of "vandalism", Réau asserted that much revolutionary destruction was motivated by cupidity, but he also claimed that to "vandals" beauty was "'une épine dans l'œil'. La beauté les offense et les humilie. Les êtres inférieurs, et qui ont conscience de leur infériorité, haïssent instinctivement tout ce qui les dépasse" ${ }^{10}$ (fig. 2). Even when discussing the foundation of the Louvre museum during the first Republic, Réau's choice of sources highlighted revolutionary resistance to, rather than support for, preservation ${ }^{11}$.

By the time of the Republic's foundation, however, legislation already protected proscribed objects that teams of artists, connoisseurs and amateurs deemed to be of sufficient aesthetic and/or historical worth to warrant preservation. In other words, sets of goods privileged by experts on these grounds had come to be recognized by the state as being autonomous of - that is to say, set apart or detached from - wider political and religious struggles and therefore worthy of physical protection. The champions of such views of culturally esteemed

2. Anonymous, Alexander Lenoir defending the monument of the Abbaye de Saint-Denis, Paris, Musée du Louvre, Rothschild collection.

3. Hubert Robert, The Bastille during the First Days of its Demolition, 1789, Paris,

Musée

Carnavalet.

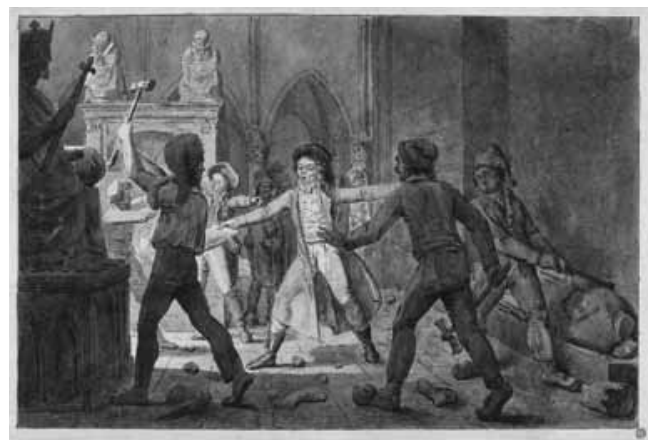
objects had lived through the latter part of a cen-

an "autonomisation du champ artistique et la transformation des images (liées à une fonction cultuelle ou politique) en œuvres d'art (liées à une fonction esthétique)"12. Christin's work is important in that it points to the emergence, particularly among the educated classes, of autonomizing discourses relating to certain images and, I would add, other kinds of particularly valued cultural objects. Since the Revolution, such discourses have gradually become more dominant, underpinning Réau's, Souchal's and UNESCO's condemnations of "vandalism." It is important to acknowledge, however, that during the period of the Revolution such views were far from being universally held. This fact explains the scale of official and unofficial object mutilations and destructions that were, and often still are, bemoaned by supporters of preservation who think about objects and their treatment in ways that differ from those whom they condemn as barbarians.

\section{New approaches to iconoclasm}

Nineteen years ago Richard Wrigley noted that there was "an extensive literature on Revolutionary iconoclasm"13. He was writing in the aftermath of the Revolution's bicentenary, a time that saw something of a surge in publications dealing with the subject ${ }^{14}$. Almost all of the authors, like several of those whose work preceded them ${ }^{15}$, eschewed the term "vandalism" as an analytical category. Many opted to write instead about "iconoclasm," choosing to more or less explicitly ignore Réau's observation that the latter word, being rooted in the Greek eikōn (image), could not be applied to the treatment of buildings (which he quite reasonably regarded as being a key part of the field of study; fig. 3). In his influential 1997 book The Destruction of Art, which focused on the centuries nessed what Olivier Christin has described as

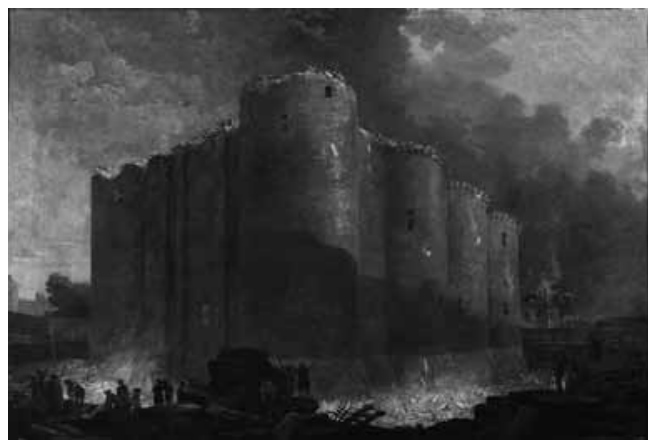


following the Revolution, Dario Gamboni shared some of Réau's reservations about the limits of the word "iconoclasm" but certainly not the earlier historian's condemnatory tendencies, suggesting the term "the destruction of art" as an alternative ${ }^{16}$. His nuanced discussion of the notion of "destruction" acknowledged that his term shared some problems with "iconoclasm" - i.e. the emphasis that both appear to place on an arguably false dichotomy between making and breaking ${ }^{17}$. Indeed, he noted that "Richard Wrigley has rightly insisted on the importance of transformation and reuse" $^{\prime 18}$, a tendency that has since become apparent in the historiography of the French Revolution that avoids pejorative references to "vandalism."

Recently, Andrew McClellan and I have taken differing but complementary approaches in essays on the same case study, that of Edmé Bouchardon's statue of Louis XV that stood in the Place Louis XV in Paris (now the Place de la Concorde) until revolutionaries pulled it down in August $1792^{19}$ (fig. 4). The tight spatial and relatively broad chronological approaches adopted in our respective studies allowed us to evidence the sculpture's contested and mutating meanings and worth to diverse audiences from its inauguration up to and beyond its toppling. Building on the work of Stanley Idzerda and Jeffrey Merrick ${ }^{20}$, we explored how the statue's meanings were regularly transformed by words that were sung, spoken, or written about (and sometimes even on) the monument ${ }^{21}$. Importantly, we also made extensive use of the visual evidence provided by drawings, prints and paintings - a choice that is surprisingly unusual in the context of the historiography of iconoclasm during the French Revolution. Many such images reinforced officially endorsed views of the royal sculpture's significance, but the lifting of censorship during the Revolution meant that images could also begin to use depictions of the statue, its overthrow, its empty pedestal, or the sculpture of Liberty that replaced it as representational resources for criticizing contemporary regimes. As such, over the course of several decades the statue was repeatedly - in Wrigley's terms - "reused", sometimes in words, sometimes in images, but eventually through the breaching of its physical integrity, which had

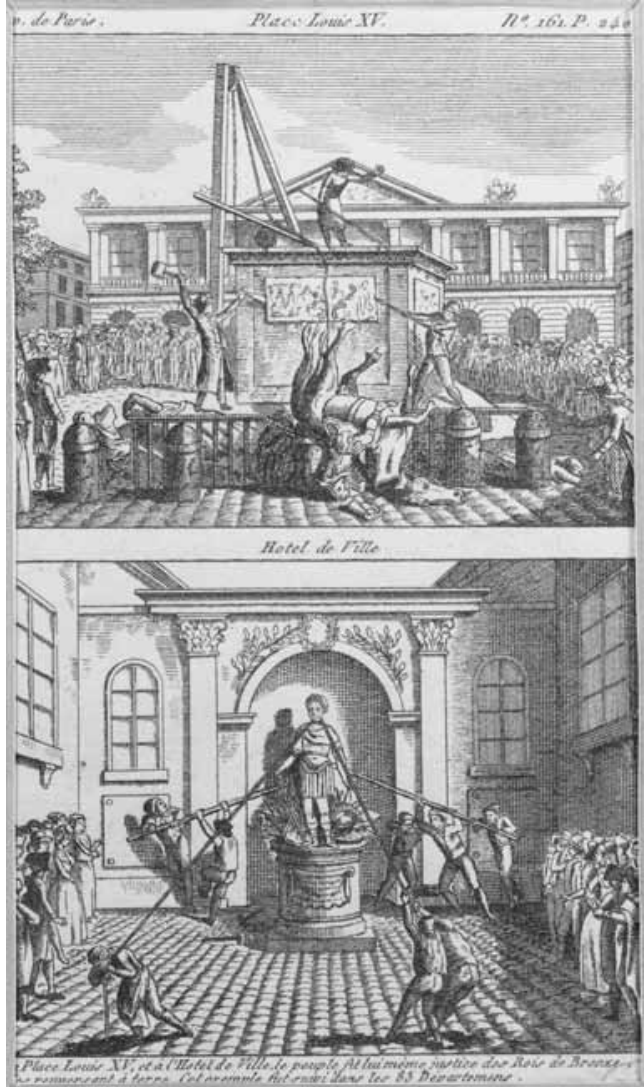

4. Anonymous Destruction of the Equestrian Statue of Louis XV in Paris in 1792

Destruction of the Pedestrian Statue of Louis XIV at the Hôtel de

Ville in Paris in 1792, Versailles, Château de versailles.

arguably become more readily imaginable and acceptable due to its earlier treatment.

McClellan's findings and mine suggest that while connoisseurs appreciated Bouchardon's statue of Louis XV as an important masterpiece and regretted its loss, many contemporaries saw the object as indissociable from wider political struggles and were therefore far less likely to resist its toppling. This observation raises questions about the extent to which images per se, and that privileged category of "art objects" in particular, were regarded in the past as being sets of signs warranting specific modes of treatment that necessarily entailed respect for an object's physical integrity on the grounds of aesthetic quality or historical value. Like Wrigley's recent book on clothing during the Revolution that discusses the trampling of cockades and liberty bonnets ${ }^{22}$ or Adrian Bantjes's writings about revolutionary Mexico ${ }^{23}$, some of my other research in this field has tended to explore the treatment of "images" or "art" but also of other types of visual signs that do not fit readily 
into such categories ${ }^{24}$. This broadening of the field of study might be seen as dangerously stretching the boundaries of "the history of art"; yet, in my opinion, the most important recent contribution to the development of scholarship on iconoclasm during the French Revolution has come from beyond that discipline and focused on objects unlikely ever to be classified as "art."

\section{Relics, religion and future research}

Huge numbers of prints, drawings, paintings, and sculptures that were damaged or destroyed during the French Revolution were religious goods housed in Churches, chapels, religious communities, or private citizens' homes. But other kinds of representational Catholic objects less readily definable as "art" or even "images," including costumes, banners, silverware, and relics, were subjected to similar treatment. It is the latter objects that are at the center of Stéphane Baciocchi's and Dominique Julia's “Reliques et Révolution française (1789-1804)", one part of a major scholarly project being undertaken at the Centre d'anthropologie religieuse européenne at the École des Hautes Études en Sciences Sociales in Paris ${ }^{25}$. Half of their 102-page study concentrates pointedly on the period preceding de-Christianisation in 1793-1794. Scholars of iconoclasm have previously paid some attention to the treatment of reliquaries in this earlier phase of the Revolution, when the material value of certain objects officially justified their melting down, while the perceived aesthetic and historical worth of others meant they were spared the mint. Baciocchi's and Julia's detailed archival work, on the other hand, is primarily concerned with the relics to which no material or aesthetic value was attributed and whose historical value was often contested even among Catholics. Their research reminds us that the treatment of relics depended in part on contemporaries' views regarding their religious value as devotional objects. For example, the market women who led numerous proces-

5. Anonymous, Order of the Procession of the Reliquary of Saint Genevieve in Paris, 1709, Paris, Archives nationales. sions to pay honor to Saint Genevieve of Paris in the summer of 1789 did so in thanks for her help in protecting the Parisians who had stormed the Bastille. To them, the relic, its reliquary, statues of the saint, her processional banners, and her confraternity's prints were intimately associated with the problems that Catholics encountered in the wider world. Baciocchi's and Julia's research suggests that a key question for historians of iconoclasm during the French Revolution involves the extent to which such non-autonomizing discourses informed the physical treatment of visual signs, including images and "art," by various groups of contemporaries.

Indeed, scholarship on relics, reliquaries, print cultures, academic painting and sculpture, and wider politico-religious debates suggests that, for many eighteenth-century French people, the primary value of a range of visual signs was religious and connected with addressing difficulties in a broader context. Most contemporaries had probably only ever been taught about the functions and worth of images in catechism classes, in church and at free Catholic primary schools, could only afford to own religious prints distributed gratis by confraternities, and most often encountered "art" in churches and chapels, or on the streets during Catholic festivals when such objects were viewed surrounded by numerous other kinds of religious signifiers (fig. 5). Daniel Roche has shown that $65 \%$ of prints that were owned by Parisian wage earners in 1780 had religious themes ${ }^{26}$. Several scholars have worked to improve understanding of the worth of religious images to diverse classes of French people, exploring subjects such as exvoto paintings in eighteenth-century France ${ }^{27}$ and confraternity prints in Paris ${ }^{28}$. Others, such as Anne Betty Weinshenker in her writings on sculpture and idolatry ${ }^{29}$, have grappled with how the production and reception of art objects related

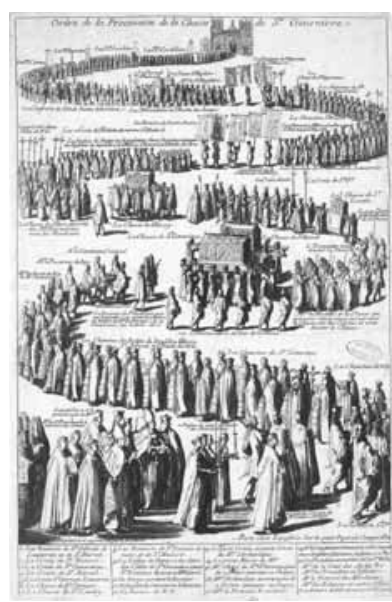

to contemporary religious debates. Nonetheless, a number of topics have yet to be exploited to the fullest. Pierre Rosenberg was right to note that Monique de Savignac's book about paintings commissioned for Parisian churches in the eighteenth 
century addressed a "chapitre négligé" in the historiography of French $\operatorname{art}^{30}$. And questions raised in influential works on religious debates of the period, such as that by Dale Van Kley on the extent and importance of Jansenist and Jesuit controversies around the Revolution ${ }^{31}$, or by Darrin McMahon on the scale of the Catholic "counterEnlightenment" ${ }^{32}$, have yet to be addressed.

Official policy on iconoclasm during the French Revolution was administered by men whose education and modes of sociability made them receptive to discourses that regarded objects of high aesthetic and/or historical worth as being set apart from wider political and social struggles (i.e. as autonomous). The views of these individuals on the exceptional status of particular objects often anticipated those held by Réau, Souchal, UNESCO and, in all likelihood, ourselves. Many of the publics of the time, however, were far less familiar with such modes of object evaluation and therefore would not necessarily have concluded that the physical integrity of politically or religiously objectionable signifiers should be respected for historical or aesthetic reasons. The scale of, and diverse responses to, iconoclasm during the 1790s suggests that such divergent modes of reception complicated the mediating roles played by visual signs in contemporary power struggles. Given this fact, our understanding of iconoclasm during the Revolution would benefit from further research into the visual cultures of Catholicism during the Age of Enlightenment, including associated modes of reception that were somewhat less likely than ours to set certain objects apart from wider struggles. Indeed, given ongoing conflicts over the treatment of contested objects, I am inclined to agree with Dario Gamboni that, "The definition and evaluation of the autonomy of art [remains] an issue whose importance cannot be overrated" ${ }^{33}$. I suspect that by addressing his point and exploring the survival of nonautonomized views of art, research into the historiography of iconoclasm during the French Revolution would be enriched. In turn, it might also help us to better understand the Taliban's destruction of the Bamiyan Buddhas and the very different responses it received in comparison to the iconoclasm of the "Arab spring."
I would like to thank my postgraduate supervisee, Lauren Dudley, for helping me to check that I had not failed to identify recent contributions to the historiography of revolutionary iconoclasm.

1. Peter Weibel, "An end to the 'end of art'? On the iconoclasm of modern art," in Iconoclash: Beyond the Images Wars in Science, Religion, and Art, Bruno Latour, Peter Weibel eds., (exh. cat., Karlsruhe, Zentrum für Kunst und Medientechnologie, 2002), Cambridge (MA)/London, 2002, p. 588.

2. In due course, some Soviet era monuments were preserved in "sculpture parks" away from more prominent public spaces in which they had once stood. It is difficult to imagine that the posters, murals, and sculptures of the Gaddafi regime will enjoy a similar fate.

3. For a detailed account of responses to the Taliban's action in the international media, see Jamal J. Elias, "(Un)making Idolatry from Mecca to Bamiyan", in Future Anterior, 4/2, 2007, p. 12-29.

4. Indeed, around 1807, Abbé Grégoire misleadingly claimed that he had "coined the word [vandalism], to destroy the thing" (see Dario Gamboni, The Destruction of Art: Iconoclasm and Vandalism since the French Revolution, New Haven, 1997, p. 18). In fact, Bernard Deloche and JeanMichel Leniaud have rectified the common misconception that Abbé Grégoire was the first to use the word vandalism, noting that its earliest recorded usage was by Joseph Lakanal, when he submitted a report on preservation of the nation's patrimony to the National Convention on June 4, 1793: Bernard Deloche, Jean-Michel Leniaud eds., La Culture des sans-culottes : le premier dossier du patrimoine 1789-1798, Paris, 1989, p. 34, n. 15.

5. Finbarr Barry Flood, "Between Cult and Culture: Bamiyan, Islamic Iconoclasm, and the Museum", in The Art Bulletin, 84/4, 2002, p. 641-659; Elias, 2007, cited n. 3.

6. Gustave Gautherot, Le Vandalisme jacobin : destructions administratives d'archives, d'objets d'art, de monuments religieux à l'époque révolutionnaire, Paris, 1914

7. Louis Réau, Histoire du vandalisme : les monuments détruits de l'art français, Paris, (1959) 1994. Réau's book begins with a section on iconoclasm before the Revolution and ends with a long discussion of the destruction of art and architecture from the First Empire until the Fifth Republic. Though not written exclusively on the subject of revolutionary iconoclasm, with more than 400 pages dedicated to the period of the Revolution, it remains the largest single study of the subject.

8. François Souchal, Le Vandalisme de la Révolution, Paris, 1990.

9. Indeed, in a longer article, it would be valuable to consider the work of Réau and Souchal in relation to the publications of a number of recent scholars, notably Dominique Poulot and Andrew McClellan, who have made preservationist discourses the foci of major studies relating to histories of "iconoclasm." See Dominique Poulot, Surveiller et s'instruire : la Révolution française et l'intelligence de l'héritage historique, Oxford, 1996; Andrew McClellan, Inventing the Louvre: Art, Politics, and the Origins of the Modern Museum in Eighteenth-Century Paris, London, 1994. 
10. Réau, (1959) 1994, cited n. 7, p. 14.

11. Admittedly, contemporary voices criticizing iconoclasm on political or religious grounds are relatively difficult to discern in the archives because articulating such opposition could render one suspect as being counter-revolutionary. All too often, we are left relying on dissenting sources writing from exile (like Abbé Barruel) or commenting some time after the events under discussion.

12. Olivier Christin, "Le May des orfèvres : contribution à l'histoire de la genèse du sentiment esthétique", in Actes de la recherche en sciences sociales, 105, 1994, p. 75 .

13. Richard Wrigley, "Breaking the code: interpreting French Revolutionary iconoclasm," in Alison Yarrington, Kelvin Everest ed., Reflections of Revolution: Images of Romanticism, London, 1993, p. 182-195.

14. Bronislaw Baczko, Ending the Terror: The French Revolution after Robespierre, Cambridge, 1994, p. 185-223; Emmet Kennedy, A Cultural History of the French Revolution, New Haven, 1989; Serge Leroux, "Tendences iconoclastes dans la pensée jacobine", in Les cahiers scientifiques, 72, 1989, p. 322-342; Simone Bernard-Griffiths et al. ed., Révolution française et "vandalisme révolutionnaire", (colloque, Clermont-Ferrand, 1988), Paris, 1992.

15. Daniel Hermant, "Destructions et Vandalisme pendant la Révolution Française," in Annales ESC, 33/4, 1978, p. 703-719; Gautherot, 1914, cited n. 6; Stanley J. Idzerda, "Iconoclasm During the French Revolution," in American Historical Review, 60/1, 1954, p. 13-26; Gabriel Sprigath, "Sur le vandalisme révolutionnaire (1792-1794)," in Annales historiques de la Révolution française, 52/242, 1980, p. 510-535.

16. Dario Gamboni, The Destruction of Art: Iconoclasm and Vandalism since the French Revolution, New Haven, 1997. Indeed, in places Gamboni pointedly used the phrase "misuse" rather than "destruction" (p. 19). Subsequently, scholars from diverse disciplines and who study various periods and cultures have also wrestled with the terminological issues tackled so succinctly by Gamboni: Stacy Boldrick, Richard Clay eds., Iconoclasm: Contested Objects, Contested Terms, Aldershot/Burlington, 2007; Leslie Brubaker, John Haldon, Byzantium in the Iconoclast Era, c. 650-850, Cambridge, 2011; Iconoclash, 2002, cited n. 1; Anne McClanan, Jess Johnson eds., Negating the Image: Case Studies in Iconoclasm, Aldershot, 2005; Erika Naginsky, "The Object of Contempt", in Yale French Studies, 101, 2001, p. 32-53; James Simpson, Under the Hammer: Iconoclasm in the Anglo-American Tradition, Oxford, 2010.

17. Gamboni, 1997, cited n. 16, p. 28-29.

18. Gamboni, 1997, cited n. 16, p. 35.

19. Richard Clay, "Bouchardon's statue of Louis XV: iconoclasm and the transformation of signs," in Boldrick, Clay, 2007, cited n. 16, p. 93-122; Andrew McClellan, "The life and death of a royal monument: Bouchardon's Louis $X V$," in Oxford Art Journal, 23/2, 2000, p. 1-28.

20. Stanley J. Idzerda, "Iconoclasm during the French Revolution," in The American Historical Review, 60/1, October 1954, p. 13-26; Jeffrey Merrick, "Politics on pedestals: royal monuments in eighteenth-century France," in French History, 5/2, 1991, p. 234-264.
21. Unlike McClellan's work, my essay draws on semiotics to describe the act of iconoclasm as a moment in an ongoing process of sign transformation that preceded, accompanied, and followed the material transformation of the sculpture-as-signifier.

22. Richard Wrigley, The Politics of Appearances: Representations of Dress in Revolutionary France, Oxford, 2002.

23. Adrian Bantjes, "The war against idols: the meanings of iconoclasm in revolutionary Mexico, 1910-1940," in Anne McClanan, Jess Johnson eds., Negating the Image: Case Studies in Iconoclasm, Aldershot, 2005, p. 41-60.

24. Richard Clay, "Violating the sacred: theft and 'iconoclasm' in late eighteenth-century Paris," in Oxford Art Journal, 26/2, 2003, p. 1-22; Richard Clay, The Transformation of Signs: Iconoclasm in Paris, 1789-1795, Oxford, 2012; Richard Clay, "Smells and bells: iconoclasm in Paris, 1789-1795," in The Journal of Eighteenth Century Studies, forthcoming (2012).

25. Stéphane Baciocchi, Dominique Julia, "Reliques et Révolution française (1789-1804)," in Philippe Boutry, Pierre Antoine Fabre, Dominique Julia eds., Reliques modernes : cultes et usages chrétiens des corps des saints des Réformes aux revolutions, 2 vol., Paris, 2009, p. 483-585.

26. Daniel Roche, The People of Paris: An Essay in Popular Culture in the $18^{\text {th }}$ Century, Berkeley, 1987, p. 222.

27. For example, Bernard Cousin, Ex-votos de Provence : images de la religion populaire et de la vie d'autrefois, Paris, 1981.

28. José Lothe, Agnès Virole, Images de confréries parisiennes, Paris, 1992. While scholarship on ex-votos has tended to focus on areas beyond Paris, it is worth noting that in 1789 ex-votos were also present in many churches in the capital. I discuss such objects and their treatment in my forthcoming book The Transformation of Signs.

29. Anne Betty Weinshenker, A God or a Bench: Sculpture as a Problematic Art during the Ancien Régime, Oxford, 2011, p. 123-158.

30. Monique de Savignac, Peintures d'églises à Paris au XVIII siècle, Paris, 2002, p. 11.

31. Dale Van Kley, The Religious Origins of the French Revolution: From Calvin to the Civil Constitution, 1560-1791, New Haven/London, 1996.

32. Darrin M. McMahon, Enemies of the Enlightenment: The French Counter-Enlightenment and the Making of Modernity, Oxford, 2001.

33. Gamboni, 1997, cited n. 16, p. 36.

Richard Clay, University of Birmingham r.s.clay@bham.ac.uk

Keywords
destruction, French Revolution, Dario Gamboni,
iconoclasm, vandalism

